\title{
Experience and Remembering
}

History and film stand in a close reciprocal relationship not just with each other, but also with discourses of memory and remembering. While historians are frequently confronted with questions about the culture of memory, film studies is dominated by the idea that films are a medium for "storing," "recording," or "disseminating" collective memory. ${ }^{1}$ Experiential approaches toward the relation between film, history, and memory, by contrast, are largely neglected or marginalized, despite the fact that we perceive film images and memories in a similar way: Both are glimpsed only as they "whizz" or "flash" by, ${ }^{2}$ remaining fragmentary yet still possessing a "hyperreal" quality. ${ }^{3}$ However, if, as Jean Baudrillard claims, it is no longer possible to disentangle our conceptions of the past and the historical reality simulated by media, ${ }^{4}$ this is due in part to a bodily experiential dimension. As Thomas Elsaesser observes, in the age of "living" pictures, history-which once seemed objective-has evaporated, while memory "has gained in status, as the repository of genuine experience." ${ }^{5}$ And so: "What more appropriate instrument to record and preserve memory than sight and sound?" This shift toward embodied experience in the function of recording and preserving memories has also brought a shift in film studies discourse in its wake. Historical films in particular are increasingly understood as a point of intersection between processes of embodied memory and historicization. Building on this idea, the first section of this chapter explores the complex interrelationship between film, body, and memory. As fundamental elements of a

(C) The Author(s) 2021

R. Greiner, Cinematic Histospheres, https://doi.org/10.1007/978-3-030-70590-9_7 
histosphere, I argue, embodied memories make it possible to experience a film's historical world as a physical reality, and add a bodily experiential dimension to the mise-en-histoire, which until now has primarily been understood as a reflective process. I elaborate on these ideas in the second section, and combine them with theories of media-generated memories. Histospheres, I shall show, draw not just on existing embodied memories and conceptions of history, but are actively involved in producing personal experiences with identity-forging potential; in a second stage, these experiences are then addressed as memories. In the third section, I examine the workings of one such stimulus-response model, whereby filmic figurations link the film's historical world to the spectator's embodied memories and produce a kind of déjà $v u$ effect. I show that forms of experience and memory are not mere effects but constitutive, interdependent processes of histospheres.

\section{Film/Body/Memory}

In the preceding chapters, I have shown how we as spectators are put into a state of immersive experience and imaginative empathy that structures our perception of the historical worlds configured by film. ${ }^{7}$ These worlds are also inscribed with historical references by a film's mise-en-histoire. ${ }^{8}$ However, whereas immersion and empathy primarily address somatic aspects of film experience, the mise-en-histoire is based mainly on constructivist-semiotic connections. One thing that links these two dimensions of histospheres together is the relation between body and memory. To illustrate this by reference to a personal film experience: In my subjective perception of the subway sequence at the start of KU'DAMM 56, embodied film experience and memory collided. At the sight of the brass handrails, I reflexively recalled the hard, smooth surfaces that my hand has touched on countless journeys on public transportation. In a moment of synesthetic reminiscence, I could even feel the shaking and vibration of the subway car, breathe the warm, stuffy air, and smell the distinctive electric fragrance of the underground. My unconscious somatic memory immediately passed into daydream. While Christian Metz uses this term to describe the simultaneous perception of film and "phantasy," Siegfried Kracauer distinguishes between two directions of dreaming. ${ }^{10}$ The first leads toward the object in the physical reality of the film: "Released from the control of consciousness, the spectator cannot help feeling attracted by the phenomena in front of him. They beckon him to come nearer."11 The 
other direction leads away from the object toward the spectator's own imagined or remembered image worlds. ${ }^{12}$ Histospheres behave analogously: Based on our experience of a film, we place ourselves in the film's audiovisually simulated historical world. At the same time, the subjective associations and mental images prompted by the mise-en-histoire cause us to drift in thought. This seeming paradox of the dream metaphor is accompanied by the exclusion of the spectator's body from many theoretical accounts, an omission that is impossible to argumentatively sustain. Thomas Elsaesser and Malte Hagener rightly point out that "it is only our capacity to perceive the external world" that ultimately allows us "to produce inner constructs of this sort." 13 With the concept of "physical reality," Kracauer introduced a bodily experiential dimension to film perception; on his view, film perception draws on a pool of basic everyday experiences, which are mainly bodily and haptic in nature and thus located at a deeper level of processing than social and political structures. In this section, I shall combine these theories with a phenomenological conception according to which memories are not solely mental states but always also involve our sensory apparatus.

There is also a close interrelation between the physiological embeddedness of memory and the medium of film. The film scholar Heike Klippel draws attention to how in cinema the "mundane and material" have permeated "the mental" to an unprecedented degree and marked out memory as an incontestable, indeterminate site "in which the physical world and mental conceptions are interwoven." ${ }^{14}$ On this theory, film functions as an "externalized process of memory," in which the spectator's biography and the film's plot interpermeate. ${ }^{15}$ This reciprocal relationship also occurs in historical films; we connect the film's historical world, which has been configured for us to perceive, with embodied memories of basic everyday experiences. A histosphere is thus composed not just of audiovisual figurations, but also of elements of our embodied memory. One example given by Vivian Sobchack in her work on embodied film experience is the enigmatic, perplexing first shot of THE PIANO (1993; dir. Jane Campion). Sobchack says that her fingers already "knew" in advance that this shot showed the view through the protagonist's hands (Figs. 7.1 and 7.2).

Thanks to her memories of her own bodily experience, her fingers "comprehended" and "grasped" the image and "felt themselves" as a "potentiality in the subjective and fleshy situation figured onscreen." 16 Sobchack's thesis that her fingers reflexively knew what her conscious mind 


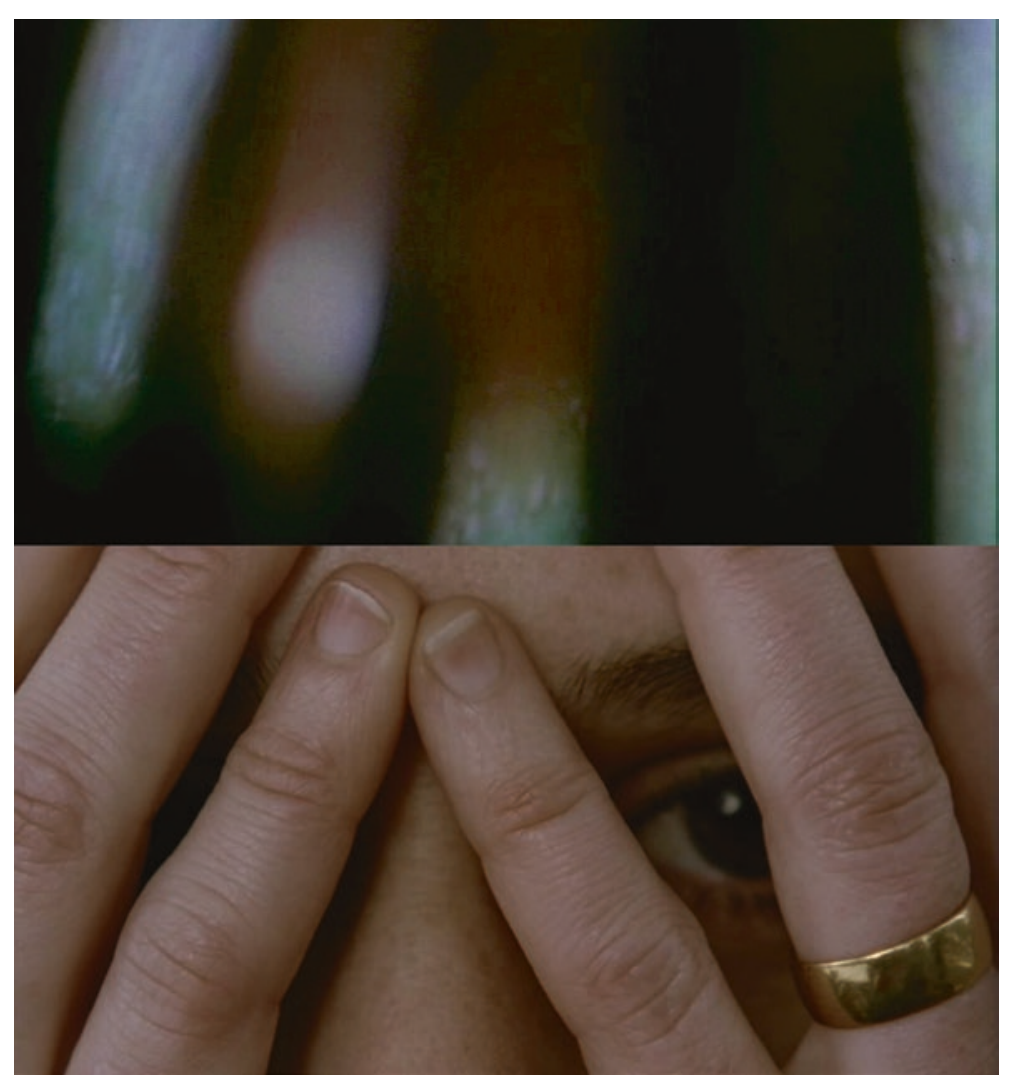

Figs. 7.1-7.2 Remembering personal bodily experience: the view through the protagonist's fingers in THE PIANO

had not yet reflectively grasped ${ }^{17}$ implies that she was unconsciously accessing memories of earlier physical-sensory experiences. A film's specific audiovisual configurations trigger the spectator's embodied memory, ${ }^{18}$ with haptic and tactile experiences occupying a privileged position in the process. As well as visually depicting surface textures, film can also impart information about the filmic world's material constitution through sound. "Materializing sound indices"19 like the dull, shuffling steps on the parquet floor in the dance school in KU'DAMM 56 evokes different embodied memories than, say, the crunching of gravel on pavement. A histosphere's 
haptic qualities are gradually pieced together based on synesthetic linkages with the spectator's embodied memories. The reliving of sensuous bodily experiences gives the histosphere a synesthetic quality through which a "somatic space of meaning" is created. ${ }^{20}$ Embodied memories of everyday experiences bleed into perceptions of the filmic world's historicity. When we see the brass handrails on the subway at the start of KU'DAMM 56, most of us will probably have an idea, based on experience and memory, of what they feel like. The film's historical world no longer seems quite so unfamiliar if we feel like we have an embodied memory of it. In YEARS OF HUNGER, the female characters are often shown sewing or folding laundry. These incidental depictions of touching various fabrics, whether a dress made of coarse cotton or fine bedlinen, can awaken in us memories of corresponding haptic experiences (Fig. 7.3).

The medium of this resonance is the skin, which represents less a boundary or dividing line between subject and world than a "semipermeable membrane $[\ldots]$ that brings world and subject into relation and makes them mutually receptive and porous." ${ }^{21}$ With regards to film's synesthetic

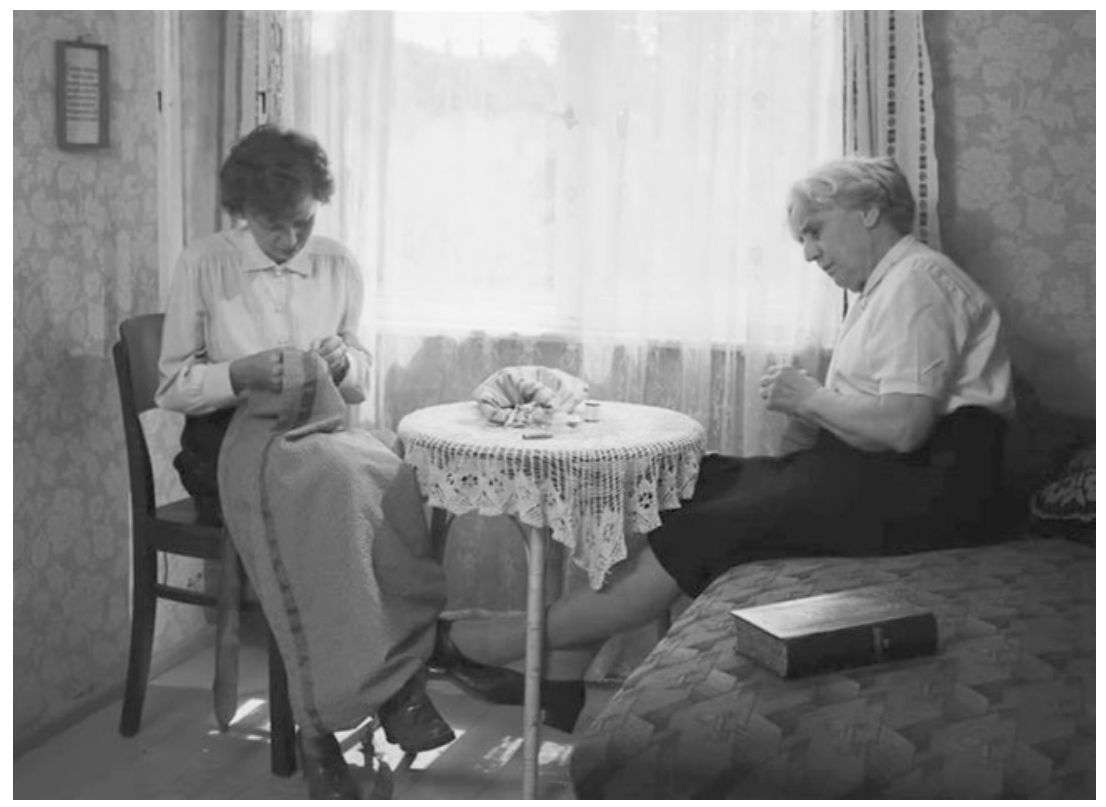

Fig. 7.3 Tactile resonance: fabrics in YEARS OF HUNGER 
potential, one particularly significant point made by Hartmut Rosa is that the skin is "a dually sensitive and literally breathing and responsive resonance organ that mediates and articulates the relation between body and world on the one hand and person and body on the other." ${ }^{22}$ The skin reacts not just to physical stimuli from the environment, but also to mental and emotional states. ${ }^{23}$ The boundary between purely physical and cognitively driven reactions is fluid. For instance, a high-pitched sound, like a person scratching a blackboard, can prompt a direct, vegetative response such as goosebumps. By contrast, we experience the shiver that runs down our spine when watching a horror film as a reaction to the combination of audiovisual stimuli and narrative relationships. As we empathetically engage with the film characters or situations, we imagine, say, how it would feel if we ourselves were being spun through the air while dancing instead of Monika. In a manner closely bound up with our capacity for empathy, this process also awakens our memories of previous lived or filmic experiences. Media theorist Laura Marks's analysis of the "skin of the film" 24 expands on Sobchack's concept of film as embodied experience: By signifying embodied memories, filmic space becomes sensuously available, enabling "contact" between the spectator and the film's represented objects. ${ }^{25}$ Marks uses a similar vocabulary to Frank R. Ankersmit in his definition of historical experience, which he claims creates the impression of "authentic contact" with the past. ${ }^{26}$ Filmic spaces' availability to sensuous, physical experience on the basis of embodied memories can also produce historical experiences of this kind. What Marks describes as the possibility of mediating intercultural experiences ${ }^{27}$ could, then, also help bridge the temporal distance to the historical past. Depictions of physical touch are especially well suited to creating a sense of intimacy and familiarity that brings the historical world simulated by the film closer by invoking primordial embodied memories and instincts. Marks draws heavily on Gilles Deleuze (although critics have rightly pointed out significant departures from Deleuze's thought in her work ${ }^{28}$ ), but I shall not consider this aspect further here as it would undermine my attempt to connect Marks's theory to phenomenological approaches to film; for whereas Deleuze's notion of the "crystal-image" implies film's desubjectivized historicity, phenomenological approaches, including the present study, focus on the subject-bound experience of history afforded by film. The potential of historical films to produce historical experiences emerges at the intersection between embodied film experience, memory, and imaginary referentialization. The skin, as in Marks's work, functions as a metaphor for a 
permeable membrane that not only spans the field of interaction between embodied and cognitive memories, but also that between autobiographical and collective memory. Attention was already drawn by Rudolf Arnheim to the interplay between film perception and "memory traces." 29 Since embodied memory structures film perception as a dynamic matrix, the unceasing production of new experiences also influences and modifies our memories of previous experiences. This continuous configuration and reconfiguration adds a bodily experiential dimension to the mise-enhistoire, which until now has primarily been understood as a reflective process. The flights of imagination prompted by a film's historical references work in tandem with the immediate sensuous experiences while watching the film and the spectator's embodied memories to help produce a historical experience.

The interplay of sensuous film experience and embodied memory also significantly influences the mode in which spectators experience the film. By contrast with older normative distinctions, Sobchack holds that fiction and nonfiction differ primarily in terms of the spectator's expectations, experiences, and evaluations. ${ }^{30}$ Based on the premise that perceptions of film images generally involve both experiential modes, she sets out the idea of a "documentary consciousness" on the part of the spectator, an embodied, normative mode of experience that in fiction films transforms irreal into real. ${ }^{31}$ Taking the example of the actual death of the rabbit in Jean Renoir's THE RULES OF THE GAME (1939), she describes how the sudden, shocking change in our understanding of the film ruptures the cinematic fiction (Fig. 7.4).

For Sobchack, the death of the real rabbit was far more shocking and unsettling than the death of the fictional human character. She ascribes this to the fact that the death of the rabbit ruptured the autonomous and homogeneous fictional space and transformed it into a documentary space. ${ }^{32}$ Modal shifts of this sort can also be observed in historical films at points where we become aware of their referential relation to the past while simultaneously feeling the film's physical reality. This gives rise to a parallel between the effect of a histosphere, which not only comprises an embodied experience but also semiotically produces historical references, and Roland Barthes's "reality effect," in which the "very absence of the signified, to the advantage of the referent alone, becomes the very signifier of realism." 33 In an analogous manner, in historical films filmic figurations take the place of historical referents. The embodied film experience does not run counter to the semiotic process but actually reinforces it by 


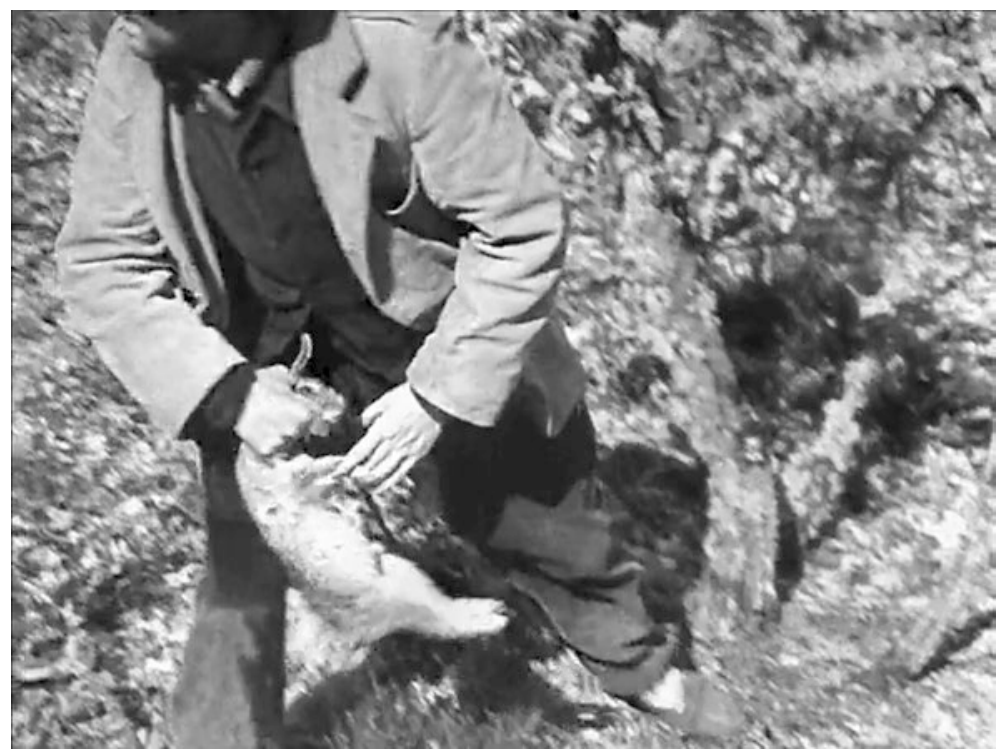

Fig. 7.4 Documentary consciousness: the dead rabbit in THE RULES OF THE GAME

making it possible to experience the film's historical world as a physical reality. The imaginative illusion thus usually remains intact while also being given the validation of factual historical authenticity. However, there can be a discrepancy between filmic figuration and historical reference; for instance, if we do not find an actor "believable" in the role of a historical figure. Such cases will seriously undermine our imaginative empathy and immersive involvement.

Sobchack's example of the dying rabbit shows that the shock effect of documentary consciousness is especially strong if the film's fictional depiction is indexically linked to an actual death. Although the route from Renoir's rabbit to the deaths at the inner German border is long and ethically fraught, very similar psychological processes are at work in both cases. The violent death of the two protagonists at the end of SKY WITHOUT STARS is even more disturbing if we know that it was not just film characters but also real people who lost their lives in a hail of bullets at the inner German border. Unlike Renoir's rabbit, the actors in Käutner's film were not actually harmed. But despite this, SKY WITHOUT STARS is also able to shockingly evoke a feeling of unease that can be understood as a reaction 
to a possible violation of ethical norms: Is it wrong to appropriate real-life deaths as an object of entertainment in fictional representations? Debates about filmic depictions of painful periods of history, in particular the question of whether the Holocaust can or should be represented on screen, also revolve around ethical questions of this kind. ${ }^{34}$ Benjamin Moldenhauer's reference to an "unease about films that tell stories of the historical past while remaining within the conventional framework of genre cinema" 35 (as discussed in an earlier chapter) describes a similar inner conflict. However, while fictional depictions of historical events do not make the spectator complicit in the suffering of actual victims, Sobchack rightly asks whether the rabbit did not also die for her and her enjoyment of the film. She is far less moved by the death of the purely fictional human protagonist than by the actual death of the animal, for she knows intuitively that the human character Jurieux (Roland Tutain) only dies in the irreal fictional space. ${ }^{36}$ It can have a similar moderating effect if a historical figure is played by a well-known actor: We know intuitively that the real person does not die, which can dilute or override the power of the historical reference to the death of an actual historical individual. The shock is diluted by the dual presence of a person as a film character and as an actor. We feel that there is "one body too much"; the imagined body of the historical person and the filmed body come into conflict. ${ }^{37}$ Matters are different when we primarily perceive the film character, either because we do not know the actor or because they embody the role so convincingly. As Sobchack puts it, film character and historical reference blend together in "the mortal gravity of the filmed event," which "transform[s] the irreality of fictional space into a different ontological order of representation-namely, into the reality of a documentary space suddenly charged with existential and ethical investment." ${ }^{38}$ However, the feelings connected to the documentary mode of experience need not be negative. The fact that the fictional historical world references actual historical events and thereby gains an intuitively persuasive "documentary" character can also trigger empathetic excitement and a sense of living involvement, an impression of "authentic contact" 39 with the historical past.

The tension between fictional and documentary modes of experience can generally be ascribed to a prereflective stage of film perception. According to Sobchack, this mode is not reflectively disclosed but physically "felt": It is our body rather than our intellect that recognizes the fundamental existential difference. ${ }^{40}$ Consequently, it is unsurprising that 
this knowledge is based on experiences linked to physical effects on the body. Whether it be the violent deaths of the rabbit in Renoir's film or the protagonists in SKY WITHOUT STARS, each of these examples relates to acts of violence and bodily destruction. This triggers a "flash" of recognition ${ }^{41}$ in which we are suddenly surprised "by the power of the object." 42 Affects and values erupt out of an existential and cultural knowledge that transcends and contextualizes the homogenizing apparatus of filmic and narrative representation, ${ }^{43}$ shifting our focus from aesthetic and narrative aspects to ethical values.

However, the shift to a documentary mode of experience need not be accompanied by a feeling of shock. If the action of the film ceases to hold our full attention, our eyes and thoughts begin to wander. ${ }^{44}$ We no longer see the film characters as subjects and part of the depicted world, but instead watch actors at work. If this happens while watching a historical film, we begin to scrutinize its historical accuracy and look for apparent errors by comparing the film with remembered historical references. A special effect can be achieved through the use of historical archive material, which results in a dual mode of spectator experience: at once documentary and fictional. ${ }^{45}$ In YEARS OF HUNGER, for instance, the difference between the aesthetics of New German Cinema and the grainy, scratchy, flickering archive footage inserted into the film creates a reflective awareness of the relation between the fictional and nonfictional elements.

As with the distinction between the actual death of the rabbit and the fictional death of the character, we already "know" at a prereflective, bodily level of film experience which audiovisual conventions and aesthetic qualities typify documentary and fictional sequences respectively. This division between fictional and documentary modes of experience can also be undermined by audiovisual devices. Ari Folman's animated film WALTZ WITH BASHIR (2008) deals with a soldier's missing memories of the Sabra and Shatila massacre that occurred at a Lebanese refugee camp in 1982 in the presence of the Israeli Army. At the end of the film, animated images of the atrocities give way to live-action archival footage of the victims' bloated corpses and the despairing, weeping survivors. This juxtaposition makes us instantly aware of the historical referentialization, retrospectively transcending the boundaries of fictional space and consciousness. This shows that a fiction can be shockingly ruptured not just by extreme situations and events within the action of a film, but also by formal interruptions of the film's montage and visual aesthetics. Even synesthetically generated haptic film perceptions that result from audiovisual activation of 
embodied memories can bring about a shift to a documentary mode of experience. However, unlike with shock, this does not create a distance or opposition between us and the film's fictional historical world, but rather expands our imaginative modeling of this world. This sort of connection between activation of embodied memory and the daydreaming described earlier in turn fosters a hybrid fictional and documentary mode of experience that does not undermine our perception of the historical world simulated by the film, but instead acknowledges and further intensifies it as a valid reality.

\section{Prosthetic Postmemory}

"In the struggle between history and memory [...] technical images have won." 46 This observation by Elsaesser about popular culture entails both a widespread "mediatization" of individual memory and an increasing blurring of the distinction between private and public images ${ }^{47}$ which would accord greater significance to processes of perception and memory that make spectators into direct witnesses to and participants in historical worlds. The great relevance of memory to our everyday perceptions is also illustrated by a previously discussed sequence from SKY WITHOUT STARS: When Anna's gaze fixes on a framed photograph hanging on the wall at her parent-in-laws' home, we intuitively believe that she is remembering something in that moment. We project our memory-infused perception of the world onto the film character. Memory "speaks" to us when we anticipate that the soldier in the picture must be Anna's late husband, Jochen's father. The film is making use here of mechanisms already described by Henri Bergson in his philosophical works from the late nineteenth and early twentieth centuries, though he did not connect these mechanisms to the medium of film that was emerging at more or less the same time. Bergson writes that "with the immediate and present data of our senses, we mingle a thousand details out of our past experience." ${ }^{48}$ Our perception thus consists of "an incalculable multitude of remembered elements" and so is already a form of memory. ${ }^{49}$ Just as this model of perception and memory corresponds to a nineteenth-century way of thinking, so too can film be understood as a technical, cultural, and aesthetic legacy of that same period. Furthermore, the historicity of the moment of production inherent in the film image gives the impression, in the words of Stanley Cavell, of participating in an event "that has happened, which I absorb (like a memory)." 50 Though Cavell does not draw a direct connection to 
phenomenology here, his reflections anticipate a core element of Sobchack's Address of the Eye: In both cases, the position of the camera outside the recorded world adverts to the absence of the spectator. We thus perceive the film as an intentional gaze of another-the cinematic subject, the camera, or the filmmaker. ${ }^{51}$ At the same time, films include us in their action, affect us like any other experience, making the filmic world sensuously available to us from the perspective of an embodied, situated cinematic subject. ${ }^{52}$ The deep-seated analogies between Bergson's model of world perception "impregnated" by memories, ${ }^{53}$ Cavell's theory of similarly impregnated film perception, and Sobchack's concept of film as embodied experience suggest that the filmic representation of historical worlds and the spectator's historical consciousness correspond especially closely in the experience of remembering. We can infer that in a histosphere, memories resulting from sensuous, embodied film experience intermingle with those "from the world of lived experiences" 54 and mark out the world simulated by the film as a valid historical experience. Alison Landsberg even suggests that

the experience within the movie theater and the memories that the cinema affords [...] might be as significant in constructing, or deconstructing, the spectator's identity as any experience that s/he actually lived through. ${ }^{55}$

This thesis is supported by studies showing that people who lived through the Second World War mix up their own experiences of the war with elements from war films such as THE BRIDGE (1959; dir. Bernhard Wicki). ${ }^{56}$ But film experiences can enter into our personal memories even if our own biography does not coincide geographically or chronologically with the historical worlds depicted on screen. For instance, as a child of the 1980s, I of course know that I did not live through the 1950s. And yet thanks to films like SKY WITHOUT STARS, YEARS OF HUNGER, and KU'DAMM 56 I can have embodied memories of the 1950s that are based on sensuous experience of historical worlds constructed by film. Our immersive, empathetic engagement with films mean that even decades later these memories seem as vivid as moments from our childhood. ${ }^{57}$ However, Klippel notes that the intermingling and interpenetration of film and the spectator's memories is not directed toward "discerning a historic truth," but rather presents the opportunity "to attain, from a decentered perspective on the self, a form of knowledge not obtainable through inference." ${ }^{58}$ By transposing August Gallinger's concept of “recollective cognition" in this way, Klippel 
formulates a fundamental condition for filmic production of historical experience as "self-experience," which in turn connects directly to the theories of Frank R. Ankersmit. ${ }^{59}$ The "authentic contact" ${ }^{60}$ with the past described by Ankersmit can likewise be found in the work of Gallinger, who writes that the remembering subject has an "immediate belief in the factuality of their previous experiences [Erlebnisse]." ${ }^{61}$ As an element of film perception, the process of remembering must consequently be ascribed crucial importance in the production of historical experience. The audiovisual figuration of a historical world is configured by our recollective cognition and refigured by the associative-recollective mise-en-histoire. Histospheres draw on two forms of memory: a prereflective, bodily form that is activated while watching a film, and a reflective, historicizing one that allows the film's historical world to be experienced as such. The first form, bodily memories activated by perceiving a histosphere, is similar in some respects to literary scholar Marianne Hirsch's concept of postmemory. In a study of descendants of Holocaust survivors, she shows that even members of the "generation after" can "remember" the "personal, collective, and cultural trauma of those who came before" even though they know them only through "the stories, images, and behaviors among which they grew up." 62 She continues:

But these experiences were transmitted to them so deeply and affectively as to seem to constitute memories in their own right. Postmemory's connection to the past is thus actually mediated not by recall but by imaginative investment, projection, and creation. ${ }^{63}$

This aspect is especially relevant to histospheres, for historical films rely on the medium's immersive, empathy-arousing potential rather than an embodied narrative performance by parents handing down memories to the next generation. Consequently, cinematic postmemory no longer has any indexical relation to actual traumatic experiences. Instead, the film's historical world is linked to the spectator's own embodied recollections and emotional memory. ${ }^{64}$ Imaginative empathy with the film's gaze and the experience of a cinematic subject are again consonant with Sobchack's phenomenological theory of a doubled address to the spectator. ${ }^{65}$ This process of subjectivation and fictionalization is also reflected at the visual aesthetic level, where there comes to be less focus on the experiences of contemporaries and archival footage, and more on their far more popular fictional recreations. For instance, film scholar Tobias Ebbrecht-Hartmann 
observes with regard to depictions of the Holocaust and National Socialism that

since the early 1990s, a visual aesthetic has increasingly emerged that no longer relates directly to historical events but rather to the media images and narratives of those events that have been handed down. ${ }^{66}$

The referentialization of filmic postmemory thereby assumes a form best described using Landsberg's concept of prosthetic memory.

The almost unbearable tension during the illegal border crossing, the close, stuffy confines of a West German postwar home in the mid-1950s, the exuberant joy of a rock 'n' roll bar from the same period: I can remember all these things despite not having been alive at that time. Historical films like SKY WITHOUT STARS, YEARS OF HUNGER, and KU'DAMM 56 produce embodied memories that in the process of the mise-en-histoire are inscribed with historical references and marked as valid historical experiences. Landsberg calls this "new form of memory" prosthetic memory; it "emerges at the interface between a person and a historical narrative of the past, at an experiential site such as a movie theater or museum." 67 "Prosthetic" refers here to the specific bodily dimension of such memories, to which Landsberg ascribes the properties of artificial limbs but which nonetheless have a sensuous, experiential component. ${ }^{68}$ Consequently, the spectator has a sense of embodied contact with the historical past. The concept of prosthetic memory thus not only bears similarities to Ankersmit's notion of historical experience, but also has the potential to shape conceptions of history and political identities. ${ }^{69}$ Landsberg notes that prosthetic memory has been intimately interwoven with the process of commodification since the early twentieth century, which "enables the transmission of memories to people who have no 'natural' or biological claims to them." ${ }^{70}$ Historical films have a special capacity to make historical worlds that lie outside our social, cultural, and geographic environment available to experience. Although there are legitimate criticisms to be made about the commodification of popular films, they do allow viewers to develop a ubiquitous historical consciousness based on prosthetic memory. Landsberg explains that "the technologies of mass culture" transform memories into a "portable, fluid, and nonessentialist" good that blurs the boundaries between personal and collective memory. ${ }^{71}$ Elsaesser expands this dynamic aspect of Landsberg's theory further. Proceeding from the hypothesis that "in popular cinema collective and individual memory are not only constructed 
and assembled, but also deconstructed and worked through," he proposes the term "parapractic memory." 72 On his theory, media memory is based on audiovisual errors that, similar to Freudian slips, "take hold in the psyche precisely in virtue of their ambiguity and reveal a truth that could not otherwise be manifested." ${ }^{\prime 3}$ Elsaesser's concept of parapractic memory lends support to the supposition that a living encounter with historical worlds simulated by film not only configures historical experiences and memories, but also produces (constantly refigured) conceptions of history. According to the historian Sylvie Lindeperg, this gives rise to "mirror structures $[\ldots]$ that make reference to earlier filmic depictions through an intertextual play of quotations and counterquotations." ${ }^{\prime 4}$ However, if most personal and collective memories and the conceptions of history constructed from them are based on media depictions, then the diagnosis of an "error" becomes essentially obsolete, since our conceptions of the past and the historical reality constructed by media can no longer be disentangled. ${ }^{75}$ Despite legitimate criticisms of the rather frivolous use of the term "prosthetic," " I shall therefore take up Landsberg's theory again and connect it to Marianne Hirsch's concept of postmemory. ${ }^{77}$ Integrating these two approaches enables a better understanding of the role and functioning of memory in filmic histospheres. For instance, the prosthetic postmemory activated in film perception is based not on intergenerational transmission of biographical experiences, but on embodied memories of film experiences. In this special form of prosthetic memory, embodied memory and historical referentialization coincide. Histospheres thus utilize two powerful processes of historicization that exponentially reinforce each other through their interaction and the fusion of personal and popular memories.

\section{ReminisCence Triggers}

Historical films not only create a multitude of highly subjective historical experiences, but also help bring about more general conceptions of history. The above-described impressions of the 1950s in the analyzed films - the tension of the border crossing, the narrow confines of the postwar home, the exuberance of a rock 'n' roll bar-draw on structures of audiovisual stimuli that I shall refer to as reminiscence triggers. In combination with our own embodied memories, they allow us to perceive the historical world constructed by the film in a mode of living encounter. This mode is enhanced by what Hugo Münsterberg calls a "certain warm 
feeling of familiarity"78 and tends to be accompanied by positive emotional responses, thereby overcoming experiences of otherness and difference from the world of our own lived experience. Unlike Kracauer's model of a "flight of associations," 79 which ultimately leads into the subjectivity of the spectator's own inner world, the concept of the reminiscence trigger takes more account of the fact that we as spectators recognize our own everyday experiences in historical films. Audiovisually communicated impressions, as well as day-to-day activities such as the unpacking of new shoes at the start of KU'DAMM 56 or the children's game of cowboys and Indians in SKY WITHOUT STARS, have the potential, in Friedrich Nietzsche's words, to create a "sympathetic resonance" 80 in the spectator's memory (Fig. 7.5).

The resonating images thus activate tap into primordial experiences such as moments of interpersonal touch, basic sensory impressions, or simple, universally relatable everyday events or encounters. Often, the underlying embodied memories are the result of media experiences. I do not need to have strolled down Kurfürstendamm myself in the 1950s to

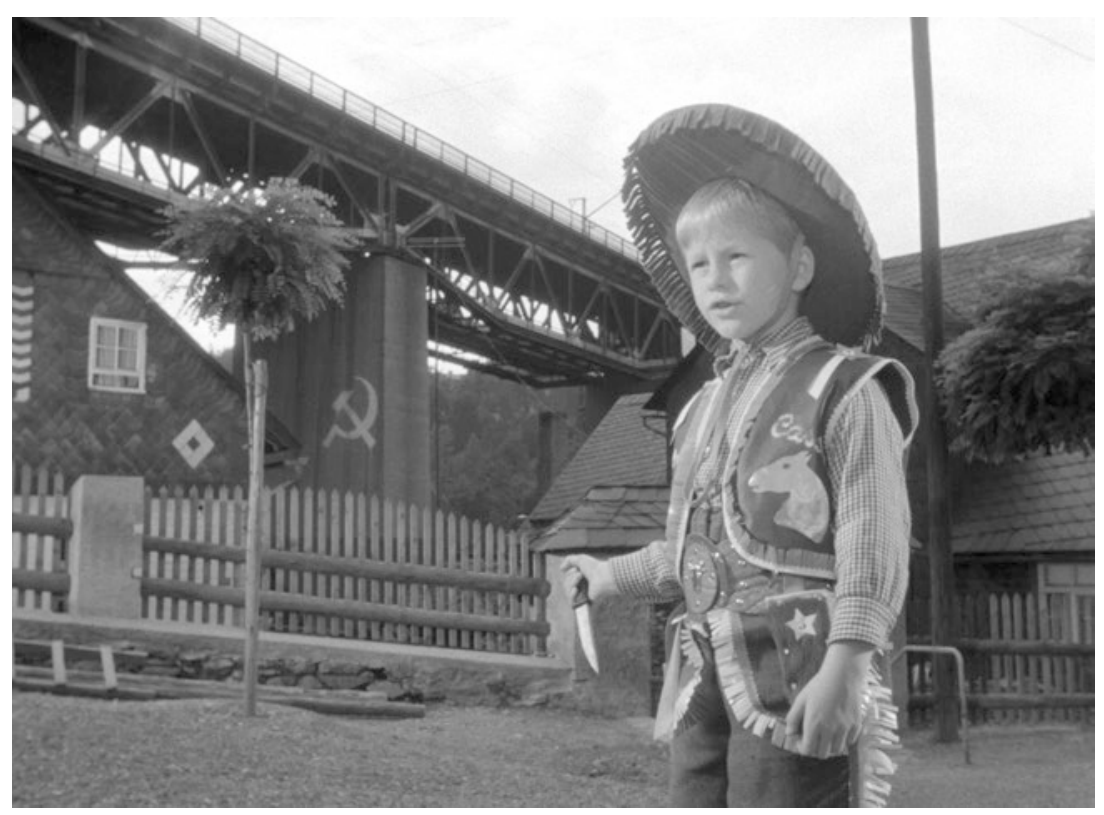

Fig. 7.5 A children's game in SKY wITHOUT STARS 
be able to remember it. Immersive, living encounters with film induce prosthetic postmemories that I can recognize in other films and that feel like my own memories. Nonetheless, at a reflective level I remain aware of the as-if nature of these postmemories. Sometimes, however, I forget, or do not realize, that these are not my actual memories. An intense yet indistinct feeling of reliving the moment sets in: I have déjà $v u$. This too can be the result of a prosthetic postmemory created by film. Anticipating this point, Béla Balázs explains: "A repetition of the set-up can stimulate the memory of some past experience and produce the well-known psychological effect of "having seen it before." 81 As a "memory of the present," 82 déjà $v u$ is like the obverse of the historical film, which (especially at the level of meaning production) comprises a making-present of the past, an actualization of the historical-virtual. However, while, say, sequences of historical newsreel footage produce a historical context in virtue of their distinctive aesthetic and thereby make the potential for recognition transparent and reflectively comprehensible, individual shots are far more indeterminate. The building by the jetty and the facade of the apartment block at the start of Jutta Brückner's YEARS OF HUNGER can only be roughly dated to a particular historical period, and are thus almost universally relatable (Fig. 7.6).

It is not just the content of the images, but also their specific formal features - the framing, the lighting, the camera movement - that can trigger a feeling of déjà $v u$, which we subconsciously connect to earlier (film) experiences.

In order to better understand the processes underlying these déjà $v u$ effects, Bergson's model of memory will once again prove helpful. Bergson uses the term "false recognition" to refer to the intense impression of the "already lived," a "complete reinstatement of one or of several minutes of our past with the totality of their content, presentative, affective, active." $" 3$ He believes that "the formation of memory is never posterior to the formation of perception; it is contemporaneous with it." ${ }^{84}$ As perception is created, memory forms alongside it, just "as the shadow falls beside the body." ${ }^{85}$ However, "practical consciousness throw[s] this memory aside" for the moment of perception, giving rise to the illusion that "memory succeeds perception." ${ }^{86}$ But if memory also seeps into consciousness in the moment of perception - if, that is, I recall a moment at the same time as living through it-I get a feeling of déjà vu. Bergson uses the metaphor of a mirror to draw a fundamental ontological distinction: While perception is "actual," a physical reality that can be touched, memory is a "virtual" 


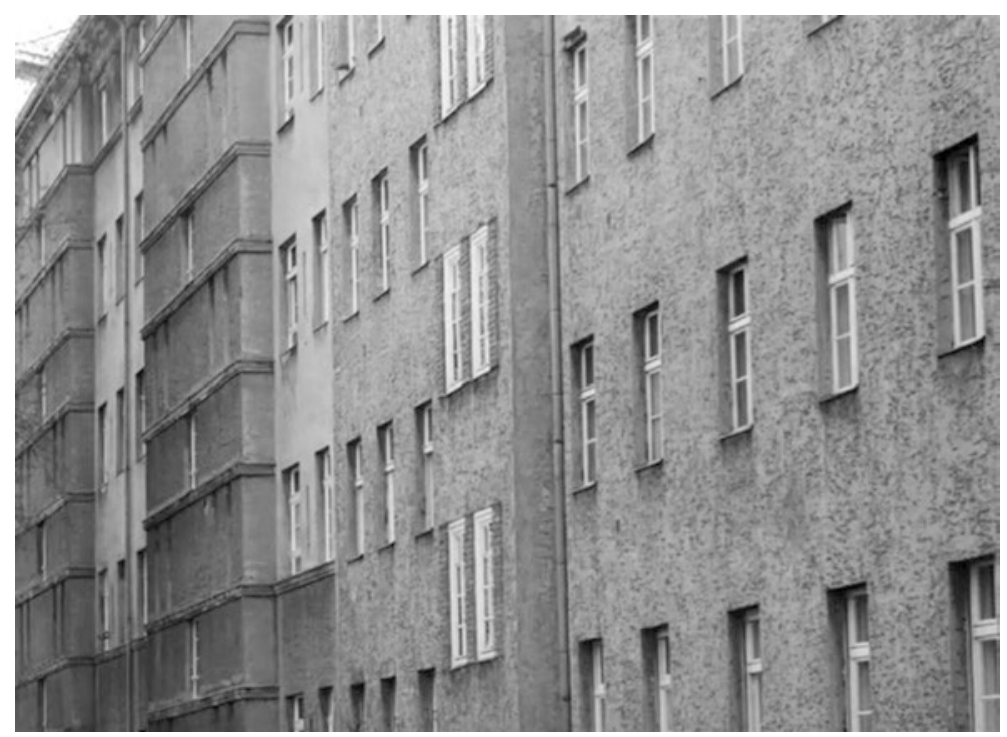

Fig. 7.6 Universally relatable settings in YEARS OF HUNGER

mirror-image. ${ }^{87}$ By contrast with Deleuze, who transposes the immanence of the virtual onto the ontology of the film image, ${ }^{88}$ here I shall concentrate primarily on a phenomenological interpretation of Bergson's theory, in full awareness that this goes beyond the epistemological limits of his reflections. Embodied film experience as described by Sobchack integrates the virtual images and sounds of a film into our perceptions of "physical reality." ${ }^{89}$ This process of connecting virtual to actual enables film experience to elicit a kind of doubling effect in the spectator. However, this is not Bergsonian déjà $v u$ in the strict sense-the symptoms are the same: the intense feeling of already having lived through the present moment. But the present moment in question is not the moment of reception. That is, the feeling here is not that of already having seen a film like this; rather, in the very moment of perception we feel as though we ourselves can recall the film's events. The embodied film experience overrides the virtuality of the filmic world, allowing it to be experienced in the present and falsely linking it to a vague memory. As Bergson puts it, memory is animated by the film's "sensori-motor elements." 90 Their ability to latch onto a wide range of extra-filmic experiences makes reminiscence triggers ideally suited 
to prompting such reactions. A film's audiovisual stimuli and the specific context and atmosphere of a certain sequence are perceived as being identical with an often blurry memory. This phenomenon lies at the intersection between Bergson's concept of memory and Sobchack's concept of film experience.

Bergson describes the self being split into two persons: "one of which appropriates freedom, the other necessity: the one, a free spectator, beholds the other automatically playing his part." ${ }^{91}$ In relation to film, Sobchack describes how the spectator sees the film's visible images as a world, that is to say, adopts the film's point of view. ${ }^{92}$ Using Bergson's terminology, we could say that we "automatically" play our part in this world. However, on Sobchack's phenomenological account of film experience, we also simultaneously perceive the film as an intentional point of view on the filmic world. ${ }^{33}$ This gives rise to another parallel with Bergson's concept of memory: For when we recognize the film's intentional point of view on the depicted filmic world as such, we also observe ourselves-as the spectator-subject that adopts this perspective on the filmic world to at least some degree. The phenomenological constellation of perspectives in film perception stands in constant interchange with our imaginations and memories: According to Klippel,

the picture $[\ldots]$ in the viewer's consciousness, is neither photographic nor from his own memory, it is a new one. It carries a specific "quality of knowledge" and provides him with an aesthetic experience which has a very concrete relationship to the world. ${ }^{94}$

Reminiscence triggers seek to produce a feeling of maximum possible similarity between the film image and the spectator's memory, so that in the moment of perception the spectator has the impression of "false recognition." The more strongly the film's immersive potential fuses the spectator's point of view with that of the film on the historical world it has simulated, the more likely this is to elicit a déjà $v u$ effect. Connecting a histosphere's simulated historical world to the spectator's embodied memories not only enables a concrete relationship to the world, but also transforms the aesthetic film experience into a historical experience. This interplay of aesthetic, psychological, and bodily elements forms the phenomenological basis for productive historical knowledge as conceived by Benjamin. Benjamin himself compares the sudden "flashing" of a dialectical image to that of involuntary memory, ${ }^{95}$ thereby anticipating the effects 
of prosthetic postmemory and reminiscence triggers. As Lena Stölzl writes, "history is not merely represented or repeated, but actively produced afresh." ${ }^{96}$ Stölzl regards this way of understanding history as a challenge posed by the concept of the dialectical image; and it is this status as "history in the making"-history conceived no longer as a finished product but as a work in progress- that enables a "live" encounter with a histosphere in its specific combination of memory and experience.

\section{CONCLUSION}

In this chapter, I investigated how the discourse of media and remembrance has shifted to embodied experience, rather than focusing on the function of storing and recording. With a view to the theory and practice of historical films, I argue that histospheres function as a point of intersection between processes of embodied memory and historicization.

Whereas immersion and empathy primarily address somatic aspects of film experience, the mise-en-histoire is based mainly on constructivistsemiotic connections. One thing that links these two dimensions of histospheres together is the relation between body and memory. We connect our perceptions of filmically configured historical worlds with embodied memories of basic everyday experiences. This adds a bodily experiential dimension to the mise-en-histoire. The reliving of sensuous bodily experiences gives the histosphere a synesthetic quality through which a "somatic space of meaning" is created. ${ }^{97}$ By considering Laura Marks's analysis of the "skin of the film"98 and Vivian Sobchack's concept of film as embodied experience, I identified a further point of connection with Frank R. Ankersmit's theory of historical experience: Filmic spaces' availability to physical experience on the basis of embodied memories also enables embodied historical experiences. This can often reduce the temporal and cultural distance to the historical past; the film's historical worlds no longer seem quite so unfamiliar if we feel like we have an embodied memory of them. At the same time, the unceasing production of new experiences also colors our memories of earlier experiences and modifies them in a continuous process of configuration and refiguration. While watching historical films, there can thus also be modal shifts in which particular actions or stylistic devices can cause the fiction to be ruptured by a documentary consciousness. However, due to their referential relation to nonfilmic events from the past, historical films have always represented a combination of fictional and documentary modes of experience, so that the 
imaginative illusion usually remains intact. Histospheres thus have an effect that mirrors Roland Barthes's "reality effect," 99 with filmic figurations taking the place of historical referents. In addition, the depicted historical worlds are given the validation of factual historical authenticity, which can lead to an expanded imaginative modeling of the constructions of the past that we experience on screen.

Building on this, I argued that histospheres draw not just on existing embodied memories and conceptions of history, but are actively involved in producing personal experiences with identity-forging potential; in a second stage, these experiences are then addressed as memories. To provide a theoretical grounding for these theses, I showed by reference to Bergson, Cavell, and Sobchack how memories resulting from sensuous, embodied film experience intermingle with those "from the world of lived experiences" 100 and mark out the worlds simulated by histospheres as valid historical experiences. The audiovisual figurations are configured by our recollective cognition and refigured by the associative-recollective mise-enhistoire. Histospheres draw on two forms of memory: a prereflective, bodily form that is activated while watching a film (which I connected to Marianne Hirsch's concept of postmemory), and a reflective, historicizing one that allows the film's historical world to be experienced as such. However, unlike in Hirsch's account of intergenerational transmission of memories, filmic postmemory does not stand in an indexical relation to the experiences underlying it. The historical worlds produced by films are instead associatively linked to our own embodied recollections and emotional memory. The referentialization of filmic postmemory is best described using Landsberg's concept of prosthetic memory. Landsberg does not regard "prosthetics" as synonymous with inanimate artifacts, but rather, as per the theory of Marshall McLuhan, as innervated, artificial extensions of the human body. ${ }^{101}$

By integrating the concepts of postmemory and prosthetic memory, I hope to have contributed to a better understanding of the role and functioning of memory in filmic histospheres. My concept of prosthetic postmemory refers to memories based not on intergenerational transmission of biographical experiences, but on embodied memories of film experiences. In histospheres, processes of bodily memory and historical referentialization thus coincide and mutually complement each other. A historical film's specific audiovisual configurations can even, I argued, trigger the spectator's embodied memories, with haptic and tactile experiences occupying a privileged position in the process. I coined the term "reminiscence 
trigger" for one such stimulus-response model, in which filmic figurations link the film's historical world to the spectator's embodied memories and produce a kind of déjà vu effect. A film's audiovisual stimuli and the specific context and atmosphere of a certain sequence are perceived as being identical with an often blurry memory. I developed a theoretical account of this phenomenon that combines Bergson's concept of memory with Sobchack's concept of film experience. The aim of this account is to show that forms of experience and memory are not mere effects but constitutive, interdependent processes of histospheres. As well as tapping into primordial experiences such as touch, basic sensory impressions, and universally relatable everyday events and encounters, reminiscence triggers can also address prosthetic postmemories engendered by films and allow us to relive them. Connecting histospheres' simulated historical worlds to the spectator's embodied memories not only enables a concrete relationship to the actual world, but also transforms the aesthetic film experience into a historical experience. Through their specific combination of memory and experience, histospheres thus enable a "live" encounter with history in the making.

\section{Notes}

1. See for example Friedrich Kittler, Gramophone, Film, Typewriter, Stanford 1999; Astrid Erll and Stephanie Wodianka (eds.), Film und kulturelle Erinnerung: Plurimediale Konstellationen, Berlin 2008.

2. Walter Benjamin, "On the Concept of History," 2005, https://www. marxists.org/reference/archive/benjamin/1940/history.htm (last accessed May 1, 2020), theses 5 and 6. See also my discussion of Benjamin's philosophy of history, whose terminology I apply to film in the section "Film experience and history" in the chapter "Film/history/ experience."

3. See on this point Heike Klippel's thesis that "the fragmentariness of film images and their memory-like hyperreality" delivers to the spectator a moving past "that they can relive precisely because it is similar to but not in fact their own." Heike Klippel, Gedächtnis und Kino, Basel 1997, p. 172.

4. Jean Baudrillard, Simulacra and Simulation, Ann Arbor 1994, p. 46.

5. Thomas Elsaesser, "'One train may be hiding another': private history, memory and national identity," 1999, http://www.screeningthepast. com/2014/12/one-train-may-be-hiding-another-private-historymemory-and-national-identity/ (last accessed May 1, 2020).

6. Ibid. 
7. See in particular the sections "Immersive experiences" and "Imaginative empathy" in the previous chapter.

8. See in particular the section "From mise-en-scène to mise-en-histoire" in the chapter "Modeling and perceiving."

9. Christian Metz, The Imaginary Signifier: Psychoanalysis and the Cinema, Bloomington and Indianapolis 1982, pp. 129-137.

10. For discussion, see Sabine Nessel, Kino und Ereignis: Das Kinematografische zwischen Text und Körper, Berlin 2008, p. 45.

11. Siegfried Kracauer, Theory of Film: The Redemption of Physical Reality, Princeton 1997, pp. 164-165.

12. For discussion, see Nessel (2008, p. 45).

13. Thomas Elsaesser and Malte Hagener, Filmtheorie: Zur Einführung, Hamburg 2007, p. 158.

14. Klippel (1997, p. 166).

15. Ibid., p. 188.

16. Vivian Sobchack, Carnal Thoughts: Embodiment and Moving Image Culture, Berkeley 2004, p. 63.

17. Ibid.

18. See the section "Reminiscence triggers" in this volume.

19. Michel Chion, Audio-Vision: Sound on Screen, New York 2019, p. 112.

20. This idea can be linked to Christiane Voss's theory of film's "borrowed body," according to which we regard "that which we simultaneously somatically (co-)constitute and experience [erleben] as being directly truthful in this form." Christiane Voss, "Filmerfahrung und Illusionsbildung: Der Zuschauer als Leihkörper des Films," in Gertrud Koch and Christiane Voss (eds.), ...kraft der Illusion, Munich 2006, pp. 81,85 .

21. Hartmut Rosa, Resonanz: Eine Soziologie der Weltbeziehung, Berlin 2016, p. 85.

22. Ibid., p. 90.

23. Ibid., p. 89.

24. Laura U. Marks, The Skin of the Film: Intercultural Cinema, Embodiment, and the Senses, Durham 2000.

25. Ibid., p. xi. Marks refers not just to memories of tactile experiences, but also to "memories of tastes, smells, and caresses that must be coaxed into audiovisual form." Ibid., p. 243.

26. Frank R. Ankersmit, Die historische Erfahrung, Berlin 2012, p. 19.

27. Marks (2000, p. 243).

28. For instance, in her review of Marks's later work Touch: Sensuous Theory and Multisensory Media, Claire Perkins draws attention to an irresolvable tension that already existed in The Skin of the Film: "For Marks the works examined are made for a viewer to feel out and constitute-they highlight 
the act of perception. For Deleuze, the set of movement-images which make up cinema are definitively not addressed to anyone-they are an Appearing." Claire Perkins, "This Time It's Personal: Touch: Sensuous Theory and Multisensory Media by Laura U. Marks," Senses of Cinema 33, 2004, http://sensesofcinema.com/2004/book-reviews/touch_laura_ marks / (last accessed May 1, 2020).

29. Arnheim implicitly connects this complex process of activating and modifying old memories and producing new ones to a bodily component when he observes that the first measures of a dance will no longer be the same "once we have seen the rest of the composition." What happens "while the performance is in progress is not simply the addition of new beads to the chain. Everything that came before is constantly modified by what comes later." Rudolf Arnheim, Art and Visual Perception: A Psychology of the Creative Eye, Berkeley and Los Angeles 1974, p. 375.

30. Sobchack $(2004$, p. 261$)$. Sobchack's view accords with that of Gertrud Koch, who likewise advocates a pragmatic, spectator-oriented perspective. See Gertrud Koch, "Nachstellungen: Film und historischer Moment," in Eva Hohenberger and Judith Keilbach (eds.), Die Gegenwart der Vergangenheit: Dokumentarfilm, Fernsehen und Geschichte, Berlin 2003, p. 226.

31. Sobchack $(2004$, p. 261$)$.

32. "For me the rabbit's onscreen death was - and still is - a good deal more shocking and disturbing than the death of the human character. And this, I would maintain, is because the rabbit's death ruptures the autonomous and homogenous space of the fiction through which it briefly scampered. Indeed, its quivering death leap transformed fictional into documentary space, symbolic into indexical representation, my affective investments in the irreal and fictional into a documentary consciousness charged with a sense of the world, existence, bodily mortification and mortality, and all the rest of the real that is in excess of fiction." Ibid., p. 269.

33. Roland Barthes, "The Reality Effect," in his The Rustle of Language, Berkeley 1989, p. 148.

34. See Gertrud Koch, Die Einstellung ist die Einstellung: Visuelle Konstruktionen des Judentums, Frankfurt 1992.

35. Benjamin Moldenhauer, "Die Lücken, die das Bild uns lässt: Geschichte, Gewalt und Reflexivität in THE ACT OF Killing und L'Image MANQUANTe," in Heinz-Peter Preußer (ed.), Gewalt im Bild: Ein interdisziplinärer Diskurs, Marburg 2018, p. 391. On this point, see also the section "Historical films" in the chapter "Fiction film and history" in this volume.

36. Sobchack $(2004$, p. 270).

37. "If the imaginary person, even in a historical fiction, has no other body than that of the actor playing him, the historical character, filmed, has at 
least two bodies, that of the imaginary and that of the actor who represents him for us. There are at least two bodies in competition, one body too much." Jean-Louis Comolli, "A Body Too Much," Screen 19:2, 1978, p. 44.

38. Sobchack (2004, p. 270).

39. Ankersmit (2012, p. 19).

40. Sobchack (2004, p. 271).

41. Benjamin (2005, thesis 5).

42. Ankersmit (2012, pp. 20-21).

43. See Sobchack $(2004$, p. 271$)$.

44. Ibid., p. 274.

45. Ibid., p. 265.

46. Thomas Elsaesser, "Geschichte(n), Gedächtnis, Fehlleistungen: FORREST GUMP," in his Hollywood heute: Geschichte, Gender und Nation im postklassischen Kino, Berlin 2009, p. 181.

47. Ibid.

48. Henri Bergson, Henri Bergson: Key Writings, London and New York 2002 , p. 96.

49. Ibid., p. 130.

50. Stanley Cavell, The World Viewed: Reflections on the Ontology of Film, Cambridge, MA, and London 1979, p. 26.

51. See Elisabeth Bronfen, Stanley Cavell: Zur Einführung, Hamburg 2009, p. 210, and Vivian Sobchack, The Address of the Eye: A Phenomenology of Film Experience, Princeton 1992, p. 56.

52. Sobchack (1992, pp. 287-288).

53. Bergson (2002, p. 96).

54. Bronfen $(2009$, p. 210).

55. Alison Landsberg, Prosthetic Memory: The Transformation of American Remembrance in the Age of Mass Culture, New York 2004, p. 180.

56. Tobias Ebbrecht, "Gefühlte Erinnerung: Überlegungen zum emotionalen Erleben von Geschichte im Spielfilm," in Tobias Ebbrecht and Thomas Schick (eds.), Emotion - Empathie - Figur: Spielformen in der Filmwabrnehmung, Berlin 2008, pp. 90-94.

57. "And yet, again like dreams, certain moments from films viewed decades ago will nag as vividly as moments of childhood." Cavell (1979, p. 17).

58. Klippel (1997, p. 183).

59. Ankersmit (2012, p. 56).

60. Ibid., p. 19.

61. August Gallinger, Zur Grundlegung einer Lehre von der Erinnerung, Halle 1914, p. 113.

62. Marianne Hirsch, The Generation of Postmemory: Writing and Visual Culture After the Holocaust, New York 2012, p. 5. 
63. Ibid.

64. This affirms the comparison drawn by Ebbrecht-Hartmann between, on the one hand, the emblematic character, repetition, and production of affect by postmemory and, on the other, "the function of stereotypes in structures of film experience [Erleben]." Tobias Ebbrecht, "Sekundäre Erinnerungsbilder: Visuelle Stereotypenbildung in Filmen über Holocaust und Nationalsozialismus seit den 1990er Jahren," in Christian Hissnauer and Andreas Jahn-Sudmann (eds.), Medien - Zeit-Zeichen: Beiträge des 19. Film- und Fernsehwissenschaftlichen Kolloquiums, Marburg 2007 , p. 40.

65. Sobchack (1992, p. 23).

66. Ebbrecht $(2007$, p. 38$)$.

67. The passage continues: "In this moment of contact, an experience occurs through which the person sutures himself or herself into a larger history [...]. In the process that I am describing, the person does not simply apprehend a historical narrative but takes on a more personal, deeply felt memory of a past event through which he or she did not live. The resulting prosthetic memory has the ability to shape that person's subjectivity and politics." Landsberg (2004, p. 2).

68. Ibid., p. 20. This also marks a point of connection between Landsberg's work and Marshall McLuhan's media theory, which defines media as extensions of the human body. See Marshall McLuhan, Understanding Media: The Extensions of Man, London 2010.

69. Landsberg $(2004$, p. 20).

70. "What separates prosthetic memory from those other experiences and makes it a phenomenon unique in the early twentieth century is its reliance on commodification. Commodification enables memories and images of the past to circulate on a great scale; it makes these memories available to all who are able to pay. Prosthetic memory, therefore, unlike its medieval and nineteenth-century precursors, is not simply a means for consolidating a particular group's identity and passing on its memories." Ibid., p. 18.

71. Ibid., pp. 18-19.

72. Elsaesser (2009, pp. 181-182).

73. Ibid., p. 182.

74. Lindeperg refers to this phenomenon as "echo-cinema." Sylvie Lindeperg, "Spuren, Dokumente, Monumente: Filmische Verwendungen von Geschichte, historische Verwendungen des Films," in Eva Hohenberger and Judith Keilbach (eds.), Die Gegenwart der Vergangenheit: Dokumentarfilm, Fernsehen und Geschichte, Berlin 2003, p. 68. 
75. See on this point my discussion of histospheres in relation to Jean Baudrillard's concept of the "hyperreal" in the section "Figuration and illusion" in the chapter "Modeling and perceiving" in this volume.

76. Sobchack criticizes approaches that use the concept of prosthetics for being reductive and simplistic, and largely leaving the people (amputees) who actually use prosthetics out of the picture. "As an effect of the prosthetic's amputation and displacement from its mundane context, the animate and volitional human beings who use prosthetic technology disappear into the background-passive, if not completely invisible-and the prosthetic is seen to have a will and life of its own." Sobchack (2004, p. 211).

77. Hirsch (2012).

78. Münsterberg uses this formulation in his theoretical reflections on the effect of advertising texts. Though he was not thinking of film, he does anticipate an important strategy for emotionally involving the spectator. Hugo Münsterberg, Grundzüge der Psychotechnik, Leipzig 1914, p. 423.

79. Kracauer gives as an example a story by Blaise Cendrars in which someone sees a cap appear to transform into a leopard. He observes this same phenomenon of spontaneous association in film: "Owing to their indeterminacy, film shots are particularly fit to function as an ignition spark. Any such shot may touch off chain reactions in the moviegoer-a flight of associations which no longer revolve around their original source but arise from his agitated inner environment." Kracauer (1997, p. 165).

80. Nietzsche uses the metaphor of "sympathetic resonance" to describe the rapid sequence and constant flow of moods to which feelings and memories attach themselves. Friedrich Nietzsche, Human, All Too Human, Cambridge 1996, p. 19.

81. Béla Balázs, Theory of the Film: Character and Growth of a New Art, Scotts Valley 2015 , p. 91.

82. Bergson (2002, p. 148).

83. Henri Bergson, Mind-Energy: Lectures and Essays, New York 1920, p. 141.

84. Bergson (2002, p. 144).

85. Ibid.

86. Ibid., p. 145.

87. Ibid., p. 147.

88. Deleuze developed the concept of the "crystal-image" to describe this phenomenon. Gilles Deleuze, Cinema 2: The Time-Image, Minneapolis 1989, 68-78.

89. See on this point Kracauer's discussion of "the redemption of physical reality" in Kracauer (1995).

90. Bergson (2002, p. 133).

91. Ibid., p. 149. 
92. Sobchack (1992, p. 56).

93. Ibid.

94. Heike Klippel, "Memory and Cinema," paper presented at the Frontiers of Memory conference, University of London, 1999, https://www.academia.edu/1721464/Memory_and_Cinema (last accessed May 1, 2020), p. 11.

95. Cf. on this topic Benjamin's notion of mémoire involontaire: Walter Benjamin, "On Some Motifs in Baudelaire," in his The Writer of Modern Life: Essays on Charles Baudelaire, Cambridge, MA, and London 2006, pp. 170-212.

96. Lena Stölzl, "Geschichte - Bild - Dialektik: Dokumentarische Historiografie und bildliche Praxis," Maske und Kothurn: Internationale Beiträge zur Theater-, Film- und Medienwissenschaft 60: Walter Benjamin und das Kino, 2014, p. 86.

97. Voss $(2006$, pp. 81,85$)$.

98. Marks (2000).

99. Barthes (1989).

100. Bronfen $(2009$, p. 210$)$.

101. McLuhan (2010).

\section{BIBLIOGRAPHY}

Frank R. Ankersmit, Die historische Erfahrung, Berlin 2012.

Rudolf Arnheim, Art and Visual Perception: A Psychology of the Creative Eye, Berkeley and Los Angeles 1974.

Béla Balázs, Theory of the Film: Character and Growth of a New Art, Scotts Valley 2015.

Roland Barthes, The Rustle of Language, Berkeley 1989.

Jean Baudrillard, Simulacra and Simulation, Ann Arbor 1994.

Walter Benjamin, "On Some Motifs in Baudelaire," in his The Writer of Modern Life: Essays on Charles Baudelaire, Cambridge, MA, and London 2006, pp. 170-212.

Walter Benjamin, "On the Concept of History," 2005, https://www.marxists.org/ reference/archive/benjamin/1940/history.htm (last accessed May 1, 2020).

Henri Bergson, Henri Bergson: Key Writings, London and New York 2002.

Henri Bergson, Mind-Energy: Lectures and Essays, New York 1920.

Elisabeth Bronfen, Stanley Cavell: Zur Einführung, Hamburg 2009.

Stanley Cavell, The World Viewed: Reflections on the Ontology of Film, Cambridge, MA, and London 1979.

Michel Chion, Audio-Vision: Sound on Screen, New York 2019.

Jean-Louis Comolli, “A Body Too Much,” Screen 19:2, 1978, pp. pp. 41-54. 
Gilles Deleuze, Cinema 2: The Time-Image, Minneapolis 1989.

Tobias Ebbrecht, "Gefühlte Erinnerung: Überlegungen zum emotionalen Erleben von Geschichte im Spielfilm," in Tobias Ebbrecht and Thomas Schick (eds.), Emotion - Empathie - Figur: Spielformen in der Filmwahrnehmung, Berlin 2008, pp. 87-106.

Tobias Ebbrecht, "Sekundäre Erinnerungsbilder: Visuelle Stereotypenbildung in Filmen über Holocaust und Nationalsozialismus seit den 1990er Jahren,” in Christian Hissnauer and Andreas Jahn-Sudmann (eds.), Medien-Zeit-Zeichen: Beiträge des 19. Film- und Fernsehwissenschaftlichen Kolloquiums, Marburg 2007, pp. 37-44.

Thomas Elsaesser, "Geschichte(n), Gedächtnis, Fehlleistungen: FORREST GUMP," in his Hollywood heute: Geschichte, Gender und Nation im postklassischen Kino, Berlin 2009, pp. 181-193.

Thomas Elsaesser, “'One train may be hiding another': private history, memory and national identity," 1999, http://www.screeningthepast.com/2014/12/ one-train-may-be-hiding-another-private-history-memory-and-nationalidentity/ (last accessed May 1, 2020).

Thomas Elsaesser and Malte Hagener, Filmtheorie: Zur Einführung, Hamburg 2007.

Astrid Erll and Stephanie Wodianka (eds.), Film und kulturelle Erinnerung: Plurimediale Konstellationen, Berlin 2008.

August Gallinger, Zur Grundlegung einer Lehre von der Erinnerung, Halle 1914.

Marianne Hirsch, The Generation of Postmemory: Writing and Visual Culture After the Holocaust, New York 2012.

Friedrich Kittler, Gramophone, Film, Typewriter, Stanford 1999.

Heike Klippel, "Memory and Cinema," paper presented at the Frontiers of Memory conference, University of London, 1999, https://www.academia. edu/1721464/Memory_and_Cinema (last accessed May 1, 2020).

Heike Klippel, Gedüchtnis und Kino, Basel 1997.

Gertrud Koch, "Nachstellungen: Film und historischer Moment," in Eva Hohenberger and Judith Keilbach (eds.), Die Gegenwart der Vergangenheit: Dokumentarfilm, Fernsehen und Geschichte, Berlin 2003, pp. 216-229.

Gertrud Koch, Die Einstellung ist die Einstellung: Visuelle Konstruktionen des Judentums, Frankfurt 1992.

Siegfried Kracauer, History — the Last Things Before the Last, Princeton 1995.

Siegfried Kracauer, Theory of Film: The Redemption of Physical Reality, Princeton 1997.

Alison Landsberg, Prosthetic Memory: The Transformation of American Remembrance in the Age of Mass Culture, New York 2004.

Sylvie Lindeperg, "Spuren, Dokumente, Monumente: Filmische Verwendungen von Geschichte, historische Verwendungen des Films," in Hohenberger and Keilbach 2003, pp. 65-81. 
Laura U. Marks, The Skin of the Film: Intercultural Cinema, Embodiment, and the Senses, Durham 2000.

Marshall McLuhan, Understanding Media: The Extensions of Man, London 2010.

Christian Metz, The Imaginary Signifier: Psychoanalysis and the Cinema, Bloomington and Indianapolis 1982.

Benjamin Moldenhauer, "Die Lücken, die das Bild uns lässt: Geschichte, Gewalt und Reflexivität in THE ACT OF KILling und L'IMAge MANQUANTE," in HeinzPeter Preußer (ed.), Gewalt im Bild: Ein interdisziplinärer Diskurs, Marburg 2018, pp. 391-411.

Hugo Münsterberg, Grundzüge der Psychotechnik, Leipzig 1914.

Sabine Nessel, Kino und Ereignis: Das Kinematografische zwischen Text und Körper, Berlin 2008.

Friedrich Nietzsche, Human, All Too Human, Cambridge 1996.

Claire Perkins, "This Time It's Personal: Touch: Sensuous Theory and Multisensory Media by Laura U. Marks," Senses of Cinema 33, 2004, http://sensesofcinema. com/2004/book-reviews/touch_laura_marks/(last accessed May 1, 2020).

Hartmut Rosa, Resonanz: Eine Soziologie der Weltbeziehung, Berlin 2016.

Vivian Sobchack, Carnal Thoughts: Embodiment and Moving Image Culture, Berkeley 2004.

Vivian Sobchack, The Address of the Eye: A Phenomenology of Film Experience, Princeton 1992.

Lena Stölzl, “Geschichte - Bild - Dialektik: Dokumentarische Historiografie und bildliche Praxis," Maske und Kothurn: Internationale Beiträge zur Theater-, Film- und Medienwissenschaft 60: Walter Benjamin und das Kino, 2014, pp. 85-94.

Christiane Voss, "Filmerfahrung und Illusionsbildung: Der Zuschauer als Leihkörper des Films," in Gertrud Koch and Christiane Voss (eds.), ...kraft der Illusion, Munich 2006, pp. 71-86.

\section{FilMOgRAPHY}

The Bridge (Die Brücke); dir. Bernhard Wicki; Federal Republic of Germany 1959. Ku'damm 56; dir. Sven Bohse; Germany 2016.

The Piano; dir. Jane Campion; Australia, New Zealand, France 1993.

The Rules of the Game (La Règle du jeu); dir. Jean Renoir; France 1939.

Sky without Stars (Himmel ohne Sterne); dir. Helmut Käutner; Federal Republic of Germany 1955.

Waltz with Bashir; dir. Ari Folman; Israel, France, Germany 2008.

Years of Hunger (Hungerjahre); dir. Jutta Brückner; Federal Republic of Germany 1980. 
Open Access This chapter is licensed under the terms of the Creative Commons Attribution 4.0 International License (http://creativecommons.org/licenses/ by $/ 4.0 /$ ), which permits use, sharing, adaptation, distribution and reproduction in any medium or format, as long as you give appropriate credit to the original author(s) and the source, provide a link to the Creative Commons licence and indicate if changes were made.

The images or other third party material in this chapter are included in the chapter's Creative Commons licence, unless indicated otherwise in a credit line to the material. If material is not included in the chapter's Creative Commons licence and your intended use is not permitted by statutory regulation or exceeds the permitted use, you will need to obtain permission directly from the copyright holder. 